\title{
Integration of Highly Skilled Migrants in the Workplace: a Multi-level Framework
}

\author{
Micheline van Riemsdijk ${ }^{1}$ (D) Scott Basford ${ }^{2}$
}

Accepted: 24 May 2021/Published online: 30 June 2021

(C) The Author(s) 2021

\begin{abstract}
This article combines literatures on immigrant integration and migration intermediaries to add a skilled perspective to theories of immigrant integration. Using a case study of foreign-born engineers in the Norwegian oil and gas industry, we develop a multi-level conceptual framework of actors that are involved in the integration of foreign-born engineers. We identified integration actors through in-depth, semi-structured interviews with human resource managers, foreign-born workers, and other integration actors. The framework is intended as a tool to move beyond single-level, unidirectional studies of immigrant integration and to provide a more in-depth understanding of the integration of highly skilled migrants in the workplace. We find that state actors fail to assist with the long-term integration for highly skilled migrants. Instead, private and voluntary actors provide information about work regulations and working life. In addition, employers and coworkers play an important role in the integration of highly skilled migrants in the workplace. We also find that highly skilled migrants can be agents of integration as they "scale up" initiatives to higher levels of decision-making.
\end{abstract}

Keywords Immigrant integration · Workplace integration · Intermediaries · Highly skilled migration $\cdot$ Engineering

Micheline van Riemsdijk

micheline.vanriemsdijk@kultgeog.uu.se

Scott Basford

scott.eric.basford@gmail.com

1 Department of Social and Economic Geography, Uppsala University, Box 513, 75120 Uppsala, Sweden

2 Oak Ridge Associated Universities, 1 Bethel Valley Road, MS-6017, P.O. Box 2008, Oak Ridge, TN 37831, USA 


\section{Introduction}

As the number of international migrants increases worldwide (International Organization of Migration, 2019), immigrant integration has become an increasingly salient issue in policymaking and public debates. ${ }^{1}$ At present, Western countries largely favor an integration approach that regards the incorporation of immigrants as a process of mutual accommodation between immigrants and the host society (de Haas et al., 2020). The bulk of these studies have focused on low-skilled migrants, whose integration needs are of the most pressing concern. Highly skilled migrants, defined as migrants who have completed a tertiary education or obtained the equivalence in experience (Salt, 1997), also experience integration challenges but have received considerably less attention from scholars and policymakers (van Riemsdijk, Basford, $\&$ Burnham, 2015). This article aims to address this gap through an examination of the actors involved in the integration of highly skilled migrants in the workplace.

Highly skilled migrants are desirable immigrants as they can fill skill shortages and contribute to economic growth and innovation (van Riemsdijk \& Wang, 2017). Although the integration of these migrants is necessary for social cohesion and beneficial for local economies (Friesen, 2011), state institutions are rarely involved in the long-term integration of highly skilled migrants. This responsibility often falls on private sector and voluntary actors. In this article, we aim to shed light on the multitude of actors that are involved in the long-term integration of highly skilled migrants. We examine the levels at which these actors operate, and the relations and fragmentations between these levels, to better understand the integration of highly skilled migrants in the workplace. The resulting multi-level framework aims to show that immigrant integration is a multi-actor, multi-directional process.

In order to identify key actors engaged in this integration process, we conducted an empirical study of the oil and gas industry in Norway. This industry has an international reach and global workforce. English is often the language of business, and oil and gas companies tend to hire foreign-born workers to meet their labor needs. These foreignborn professionals are hired for their specialized skills in, for example, valve technology, subsea pipeline welding, and the design and maintenance of oil platforms.

The study makes three theoretical contributions to the immigrant integration literature. First, we examine integration actors at multiple levels of analysis - broadening the widespread notion of integration as a two-way process of interaction between immigrants and state institutions in a host society. Second, we provide insights into the integration of highly skilled migrants, which has been understudied. Building on research on the integration of low-skilled migrants, we identify actors and levels of integration and incorporate these understandings into a multi-level framework of skilled migrant integration. Third, we bring together theories of immigrant integration and skilled migration intermediaries (Groutsis et al., 2015; Harvey et al., 2017) to identify state and non-state actors that shape the workplace integration of highly skilled migrants. Intermediaries can be defined as "brokers" who provide services for highly skilled migrants and help shape international skilled migration flows and outcomes.

\footnotetext{
${ }^{1}$ In the year 2019, the number of international migrants worldwide was estimated to be 272 million (3.5\% of the world's population), increasing from 150 million in the year 2000 ( $2.8 \%$ of the world's population) (International Organization for Migration, 2019).
} 
While the literature on skilled migrant intermediaries has examined recruitment and destination choices, we adapt this body of research to the long-term integration of highly skilled migrants.

The article is organized as follows. We first provide a short overview of theoretical approaches to the integration of immigrants, paying particular attention to the actors and levels of authority that are involved in the integration process. This is followed by a discussion of research methods. We then present a multi-level framework for the integration of foreign-born engineers in Norway's oil and gas industry and discuss its contributions to the existing literature on immigrant integration.

\section{Theoretical Approaches to Immigrant Integration}

This section examines theoretical approaches to immigrant integration, analyzing the actors and institutions that are involved in the integration process. We first discuss the evolution of assimilation and multicultural and integration perspectives on immigrant incorporation, followed by a review of the context of reception at the national and subnational levels and immigrant integration in the workplace. We incorporate these insights into a multi-level conceptual framework that includes the actors and levels involved in the integration process. Thus, we provide a more holistic understanding of immigrant integration, examining the inter-linkages and disconnects among various integration actors at multiple levels.

\section{Ideologies of Immigrant Integration}

The reception of immigrants has historically been governed by policies of assimilation, which were implemented during the mass emigrations of the nineteenth century. Assimilation policies place responsibility on newcomers to adapt to the social and cultural norms of the host society and to give up the social, cultural, and linguistic characteristics of their country of origin. Thus they would eventually "blend into" the receiving society, which would change little - if at all (de Haas et al., 2020).

Starting in the 1960s, concerns regarding the erasure of immigrant cultural identity gave rise to policies that promoted multiculturalism and pluralism. Multicultural policies aimed to grant immigrants equal access to rights and resources. Canada has been highlighted as a success story of multiculturalism, as its immigrants are more likely to become citizens, to vote, and to be involved in politics compared to other Western countries; immigrant children have better education outcomes; and Canadians are more positive about immigration compared to citizens in other Western democracies (Kymlicka, 2012: 79-80).

Critics argued in the 1990s that multicultural policies provided little incentive to learn the language or otherwise adopt the values of the host society (Koopmans, 2010). They alleged that multicultural policies failed to incorporate immigrants into the host society and that the lack of integration contributed to tensions between immigrants and the majority population. Thus, while assimilation policies did not acknowledge cultural difference as a resource, multicultural legislation failed to give immigrants sufficient cause to acculturate. In Norway, the immigrant integration process was also widely perceived to be unsatisfactory, prompting policy responses that emphasized reciprocity and the duty of immigrants to participate in society (Brochmann \& Djuve, 2013). 


\section{Context of Reception}

At the national level, professional and regulatory organizations shape the integration of highly skilled migrants. Girard and Bauder (2007) have examined the role of Professional Engineers Ontario in the assimilation and exclusion of foreign-born engineers. They argue that regulatory organizations institutionalize expectations for Canadaspecific cultural norms in the professional community, including the "correct" behavior of engineers. These norms govern acceptable workplace behaviors, practices, and professional ethics. Immigrant workers acquire this professional habitus when they start working in the country of destination, internalizing "proper dispositions and perceptions" (Girard \& Bauder, 2007, 50).

In Scandinavian countries, the welfare state ideology shapes integration initiatives at the national and local level. The Nordic welfare model provides universal welfare services, paid for by taxes, and is founded on ideals of equal access and opportunity for all (Esping-Andersen, 1996). The government is responsible for providing practical assistance for newcomers and their incorporation into the host society (Hernes et al., 2019), although these efforts primarily target lower-skilled migrants. These initiatives aim to help immigrants become "good citizens" who adopt the values of the Nordic welfare model; thus, "integration has become imbued with moral and cultural values concerning what it takes to be a proper citizen and member of the local society" (Olwig, 2011, 194).

The sub-national context of reception also matters, as highlighted in studies of multilevel governance of migration (e.g., Feltenius, 2016; Spencer, 2017; Zapata-Barrero et al., 2017). Ellis and Almgren (2009) blame "methodological nationalism," which pays most attention to the role of national-level institutions in international migration and integration (Wimmer \& Glick Schiller, 2003), for a lack of attention to integration processes at the sub-national level. They observe that sub-national levels matter in the USA, where state governments, municipalities, and voluntary organizations are responsible for the delivery of welfare services to immigrants. We concur with the authors that scholars should study the national and sub-national levels without assuming a priori that actors at the national level are most powerful.

Relatedly, scholarship on skilled migrant intermediaries (Groutsis et al., 2015; Harvey et al., 2017) integrates macro-, meso-, and micro perspectives on the destination choices of highly skilled migrants. The authors identify various actors that help shape skilled migration flows and examine how country, city, and organization reputations inform migrants' destination choices. Building on Xiang (2012) and Lindquist et al. (2012), the research links the activities of actors across levels, helping us better understand how intermediaries and destination reputations intersect. The authors' identification of new intermediaries is of particular interest to our work, as it provides a more complete understanding of factors that shape international skilled migration flows and in our research highly skilled migrants' integration.

Next, we shortly survey the literature on the integration of highly skilled migrants in the workplace. This topic has started to received attention from scholars in migration studies and human resource management, but they generally study a limited number of actors and levels involved in the integration process. In addition, policymakers have tended to overlook the integration needs of highly skilled migrants. This article aims to address these lacunae. 


\section{Integration of Highly Skilled Migrants in the Workplace}

Among the most widely cited works about the integration of migrants in the workplace is Hofstede's Culture's Consequences-International Differences in Work-Related Values (first edition 1980). In this book, Hofstede developed a typology of national workplace cultures. The framework was expanded by Hofstede et al. (2005), who argued that individuals' behaviors can be explained by these factors: power distance, collectivism vs. individualism, femininity vs. masculinity, uncertainty avoidance, longvs. short-term orientation, and indulgence vs. restraint.

While Hofstede's work is widely known in cross-cultural management research, its arguments have come under considerable scrutiny. Criticism centers on what McSweeney $(2002,112)$ calls "fallacious assumptions" based on a manipulation of quantitative data that produces an exaggeration of static, nation state-based cultures and the uniformity of their influence on citizens. Moreover, some scholars question the ability to define culture in quantifiable fragments (Baskerville, 2003; McSweeney, 2002; Shenkar, 2001), let alone from an outsider's perspective (Baskerville, 2003). Other prominent criticisms include Hofstede's failure to incorporate managers who actually make decisions and work with migrant employees (Guttormsen, 2016; Harzing, 2001) and the omission of context-specific variables that influence behavior (Gerhart \& Fang, 2005). These shortcomings have been rectified with empirical studies of immigrant integration in the workplace, as we discuss below.

Friesen (2011) studied the professional integration of foreign-born engineers in Canada, applying a social and human capital and habitus perspective. She found that foreign-born engineers needed to acquire cultural skills such as language proficiency, communication skills, and an understanding of the tacit norms of professional behavior and organizational culture in order to succeed professionally. Employers also emphasize the importance of "soft" skills, including interpersonal skills and the ability to read body language. The Canadian employers in Friesen's study place the onus of integration on the foreign-born engineers, but she notes that companies also have a responsibility to integrate newcomers.

In a study of the workplace integration of highly skilled migrants in Calgary and Edmonton, Lai et al. (2017) examined the roles of employers and immigrant-serving organizations, as well as the integration strategies of immigrants themselves. They found that migrants enroll in continuing education to enhance professional knowledge and skills, gain professional experience through internships or on-the-job training, and participate in professional mentorship programs. Interestingly, informants recommended diversity training for employers and native-born coworkers as well as immigrants to foster cultural awareness and an inclusive workplace. This initiative would place the responsibility for workplace integration on all actors involved.

The literature on diversity management has noted a lack of preparedness of HR staff to accommodate and make efficient use of their teams' diversity. Friesen and Ingram (2013) have observed that managers in engineering firms in Canada often have little diversity management experience. In a study of internship programs, they found that most managers used ad hoc strategies in the absence of company programs. Managers with little intercultural management experience would complain about the "deficits" of foreign-born engineers compared to Canadian workers. Over time, managers acknowledged that the cultural differences between their employees resulted in different 
behaviors, noting the "difference" among their employees rather than their shortcomings. These employers learned to understand that difference can be a strength and to acknowledge the importance of creating a welcoming environment for foreign-born engineers.

Mahmud et al. (2014) studied the workplace integration challenges of foreign-born information technology (IT) workers and engineering professionals in Australia. They identified a lack of English language proficiency and communication skills, qualifications, and differences in societal and workplace culture as the main obstacles to longterm integration. They note that these challenges are partly attributable to the personal characteristics of migrants but also employers' mindset and assessment of foreign-born workers. Mahmud et al. argue that employers should adjust their HR policies and training modules to better meet the needs of a multicultural workplace, thus partially placing the integration responsibility on employers.

Focusing on integration initiatives at the local level, Plöger and Becker (2015) studied local opportunity structures and modes of incorporation for highly skilled migrants in Dortmund and Hamburg. They found that the characteristics of the work environment significantly influence the integration practices of highly skilled migrants. English-language workplaces, such as universities and research institutes, make it easier for foreign-born workers to meet other foreigners, but these employees may have limited interaction with people outside the workplace. In less international work environments, it is imperative to speak German to become acquainted with coworkers. Their findings show that the size of the organization, ethnic composition of the workforce, and language of business all matter in the integration of highly skilled migrants.

The literature review presented above provides important insights into the workplace integration of highly skilled migrants. These studies, however, examine only one or two actors involved in the workplace integration process and take a mono-level perspective (focusing predominantly on the national, local, or personal level). Thus, we lack a systemic analysis of the workplace integration of highly skilled migrants that takes the multitude of actors and levels of authority into account. This article responds to this research gap by developing a multi-level framework for the study of the workplace integration of highly skilled migrants.

\section{Labor Migration and Employment of Foreign-Born Workers in the Oil and Gas Industry in Norway}

Until recently, Norway has predominately been a country of emigration. Although this began to shift in the mid-twentieth century, as late as 1992, only $4 \%$ of the Norwegian population was foreign-born, and many migrants were of Scandinavian origin. By 2021, however, the number of immigrants and persons with foreign-born parents is $18.5 \%$, comprising a much broader range of origins (Statistics Norway, 2021). The ethnic and racial diversity of Norway is most pronounced in Oslo, where 33\% of the population are now first- and secondgeneration immigrants (Sandnes, 2017). State actors have developed services to accommodate immigrants, but these are focused disproportionately-if not entirely-on low-skilled migrants. 
Norway is an attractive destination for foreign-born engineers due to its advances in subsea technology and other petroleum-related technologies, high salaries, and generous welfare benefits. ${ }^{2}$ The country experienced the largest influx of labor in 2011, when almost 27,000 labor migrants entered the country (Statistics Norway, 2019). ${ }^{3}$ Since then, the number of labor migrants has declined each year, with an eventual return to the 2011 level in 2018. The recent decline in labor migrants can be attributed to a downturn in the Norwegian economy and improving labor markets in countries of origin (Tønnessen et al., 2017). Labor migrants are the largest group of immigrants in Norway, followed by family migrants, refugees, and students (Statistics Norway, 2019).

According to the latest data available, 6927 (11.5\%) foreign-born workers were employed in the Norwegian oil and gas industry in 2016. The majority came from Western Europe, and the most common countries of origin were Great Britain, Poland, Sweden, Germany, France, Denmark, Iran, India, and Russia (Ekeland, 2017). In 2014, the largest number of foreign-born workers in the industry was recorded, with over 10,000 employees (13.0\%) (ibid.). Since then, employment in the oil and gas industry has declined due to a significant drop in oil prices.

\section{Methods}

The findings in this study are derived from fieldwork research conducted in Norway between 2011 and 2014. During that time, Norway experienced a high demand for its oil- and gas-related products and services. Companies recruited many engineers and other highly skilled migrants from abroad to fill labor shortages. This situation changed considerably soon after the fieldwork was concluded, as lower oil prices contributed to extensive layoffs in Norway's oil and gas industry.

The results presented in this article are based on semi-structured, in-depth interviews with four Norwegian human resource managers, three foreign-born line managers, four advisors for the European Employment Services, and four representatives for relocation agencies regarding their integration initiatives for highly skilled migrants. In addition, interviews were conducted with eleven foreign-born engineers regarding their experiences in Norway and integration in the workplace (for an overview of study participants, see Table 1).

Interviews were conducted in five oil and gas companies that attract a large number of foreign-born engineers, located in three Norwegian cities. The companies range in size from 2000 to 12,000 employees and include one Norwegian-owned and four foreign-owned companies. EU/EEA citizens constitute a large proportion of the foreign-born, while some companies have recruited a sizeable number of engineers from South Asia as well. Companies that hire foreign-born engineers were identified in online articles on human resources in the oil and gas industry, conferences on the recruitment of highly skilled migrants, and through interviews with foreign-born engineers and human resource managers who named and/or recommended other companies. In order to gather a broad sample

\footnotetext{
${ }^{2}$ Salaries in Norway are among the highest in the world, but workers also pay high income taxes. For highly skilled engineers in the petroleum industry, salaries are higher in the USA and Brazil than in Norway.

${ }^{3}$ The number of labor migrants reported by Statistics Norway
} 


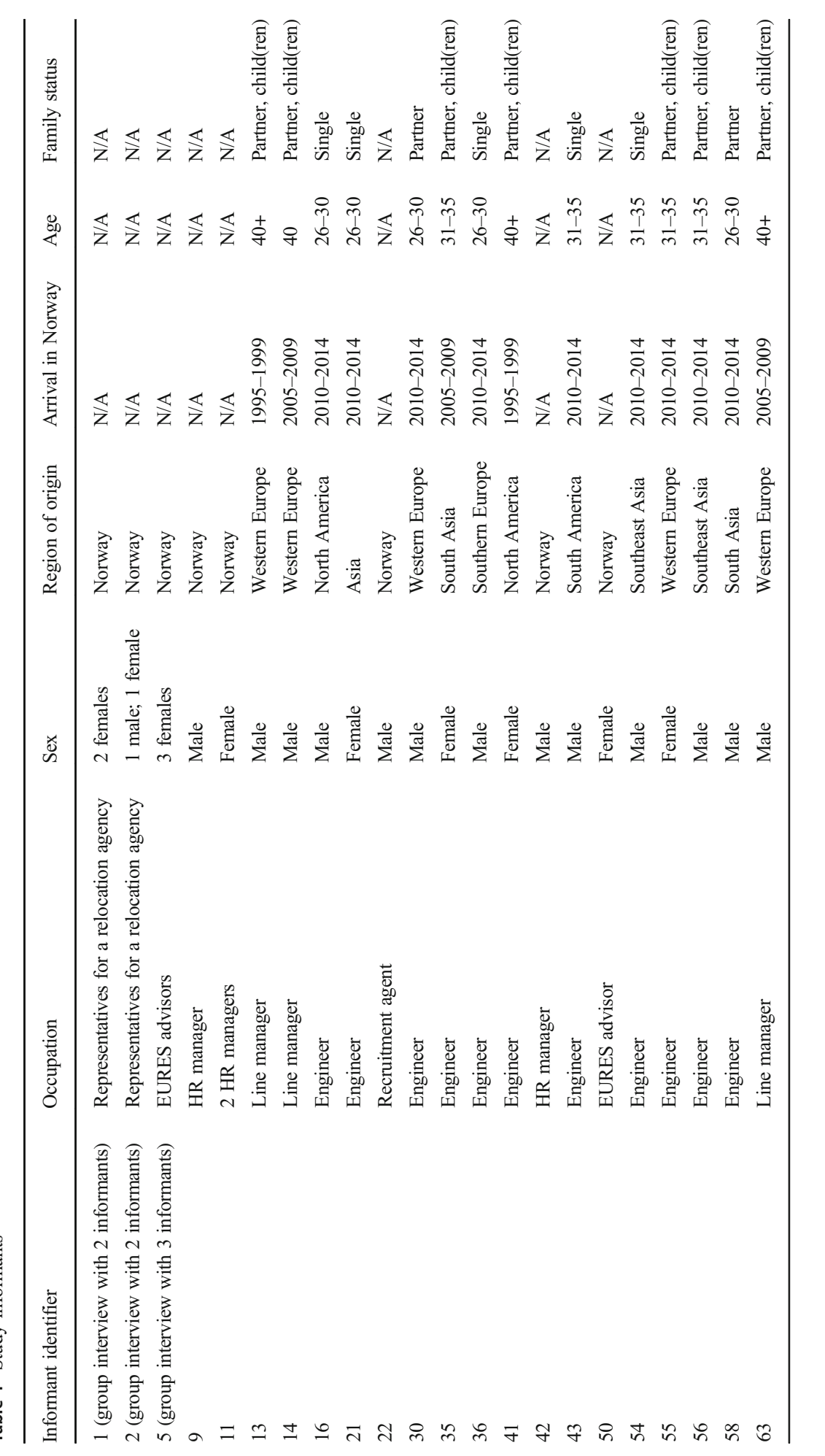


of employees in terms of country of origin, residence in Norway, sex, race/ethnicity, and age, a targeted snowball sample was used, asking managers and foreign-born engineers to recommend informants who were underrepresented in the sample.

To broaden the sample of foreign-born engineers, three gift card recipients were interviewed as well. The first author administered a survey about workplace integration in two companies and selected three winners using the Excel random number generator. She personally delivered the gift cards and invited each recipient to participate in an interview. All foreign-born engineers that were interviewed were awarded permanent contracts and had lived in Norway for at least 1 year.

We coded the interview transcripts for key integration actors and strategies. After devising an initial list of key actors, we ensured the validity of the data through respondent validation (Baxter \& Eyles, 1996), contacting key actors to obtain more information about their role in the workplace integration of highly skilled engineers. In addition, follow-up interviews were conducted with a human resource manager and a foreign-born engineer to assess the importance of the identified integration actors. The actors and initiatives were then included in a multi-level framework for the workplace integration of highly skilled migrants (see Fig. 1).

\section{Findings}

In this section, we present the actors and institutions that are involved in highly skilled migrant integration in the workplace, as depicted in Fig. 1. We start at the international

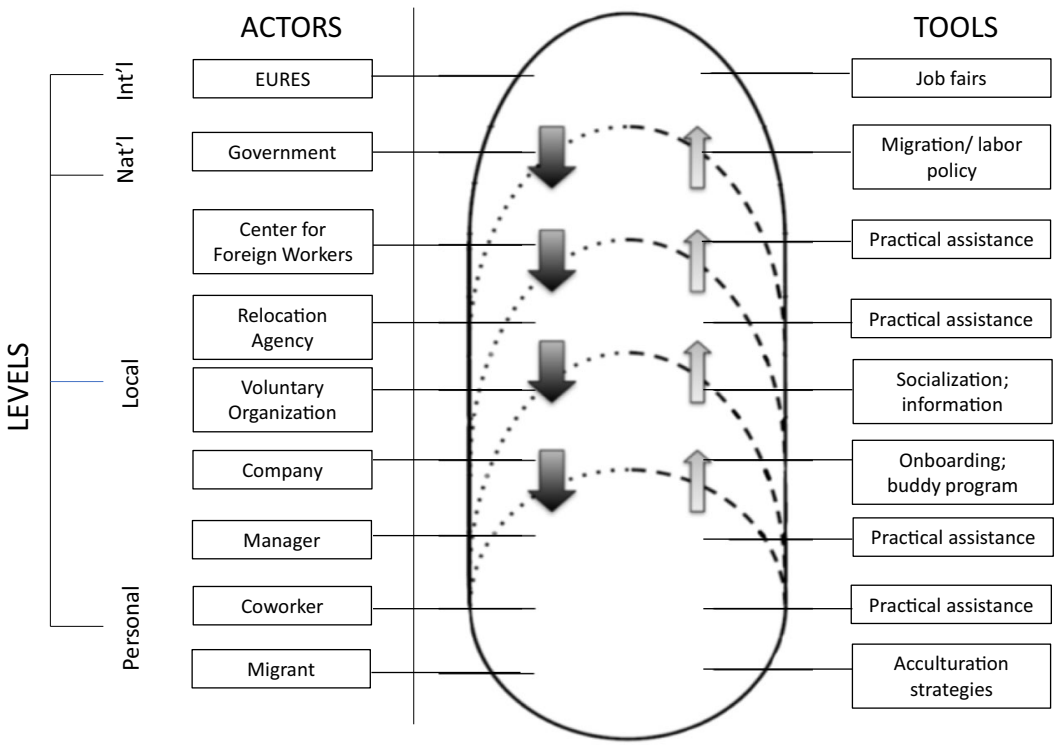

LEGEND

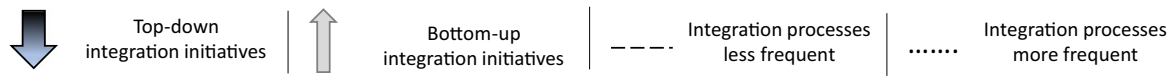

Fig. 1 Multi-level framework for the integration of highly skilled migrants in the workplace 
level, followed by the national, local, and, lastly, the personal level, highlighting interlinkages and fragmentation among levels.

The framework that we developed depicts the integration process as multidirectional rather than a two-way process involving a "host society" and immigrants. We used the literature on the integration of highly skilled migrants (discussed above) to identify actors involved in the integration process. In the interviews, we identified additional actors, the level(s) at which they operated, inter-linkages between these actors, and disconnects between levels.

The integration of foreign-born engineers in the workplace is a multi-directional process, represented by arrows and dotted lines in the framework (see Fig. 1). Actors that operate at "higher" levels of analysis generally exert more power and influence. Their top-down integration activities are represented by the large downward-facing arrows and more permeable boundaries separating actors, as these initiatives are more common than bottom-up initiatives that are represented by thinner arrows and less permeable lines.

In the following sections, we provide an overview of key actors that are involved in the workplace integration of highly skilled migrants, moving from the international to the personal level. We have summarized their integration activities in Table 2 and will discuss their roles in more detail below.

Table 2 Integration actors, functions, and scales of operation

\begin{tabular}{|c|c|c|}
\hline Actor & Scale & Integration function \\
\hline $\begin{array}{l}\text { European Employment } \\
\text { Service (EURES) }\end{array}$ & International & $\begin{array}{l}\text { Acts as a "culture broker" between job seekers and employers, } \\
\text { providing culture-specific information necessary for mutual un- } \\
\text { derstanding }\end{array}$ \\
\hline Government & National & $\begin{array}{l}\text { Immigration and labor market policies govern the admission of } \\
\text { highly skilled workers from non-EEA countries and can pose } \\
\text { considerable obstacles to their integration in the workplace }\end{array}$ \\
\hline $\begin{array}{l}\text { Center for Foreign } \\
\text { Workers }\end{array}$ & National & $\begin{array}{l}\text { A "one-stop-shop" where immigrants can register with the } \\
\text { Directorate of Immigration, the police, and tax authorities }\end{array}$ \\
\hline Relocation agency & Local & $\begin{array}{l}\text { Provides practical support upon arrival, including the application } \\
\text { for a national identity number and tax card, housing search, } \\
\text { school selection, child care, language training, and provides } \\
\text { information about working culture }\end{array}$ \\
\hline Voluntary organization & Local & $\begin{array}{l}\text { Offers networking opportunities with immigrants and native-born } \\
\text { and provides information about working culture }\end{array}$ \\
\hline Company & Local & $\begin{array}{l}\text { Provides onboarding programs, networks for young employees, } \\
\text { practical assistance }\end{array}$ \\
\hline Manager & Personal & $\begin{array}{l}\text { Informs migrant workers about living and working in the country, } \\
\text { provides practical assistance }\end{array}$ \\
\hline Coworker & Personal & $\begin{array}{l}\text { Provides information about practical issues and insights into } \\
\text { workplace norms and company culture }\end{array}$ \\
\hline Migrant & Personal & $\begin{array}{l}\text { Develops personal acculturation strategies to address integration } \\
\text { challenges }\end{array}$ \\
\hline
\end{tabular}




\section{International-Level Integration Actor}

\section{European Employment Services (EURES)}

The European Employment Service (EURES) links employers and job seekers across national borders. This agency was established by the European Commission to promote employment mobility within the European Economic Area (EEA) (European Commission, 2020). It organizes international labor recruitment fairs for shortage professions in EEA member states and invites international employers to participate. In this process, EURES acts as a broker between job seekers and employers, providing information to both actors (Groutsis et al., 2015; Harvey et al., 2017). Before employers participate in the job fair, EURES advisors explain the degree system, university rankings, and cultural codes. A EURES advisor explains:

We'd made fact sheets concerning the education system in Portugal, language competencies, which universities are ranked high, how to look at education. . . . So we try and prepare the companies sufficiently so they actually know what to look for on a CV. (informant 50)

At the fair, EURES advisors give English-language presentations for job seekers about living and working in the countries represented, introducing the employment laws, social security system, and work culture (Verwiebe et al., 2010). Two HR managers in our study used EURES to hire Portuguese engineers, and two Portuguese respondents had found employment in Norway through the agency.

EURES is an example of the successful interlinkage of integration initiatives across the international (EURES), local (company), and individual level (human resource managers and foreign-born engineers) (Lindquist et al., 2012; Xiang, 2012). EURES advisors "link" local employers and job seekers at the international job fairs and teach both parties about country-specific cultural norms, values, and professional expectations. Thus, EURES representatives help job seekers and employers acquire intercultural competencies that are necessary for mutual understanding (Friesen \& Ingram, 2013).

These initiatives are small-scale and only available to EU/EEA citizens. In a broader perspective, however, EURES' intercultural efforts can help improve employers' assessment of foreign-born workers (Mahmud et al., 2014), which also benefits migrants who arrive through other recruitment channels.

\section{National-Level Integration Actors}

\section{Government Actors}

National migration regulations can give preference to highly skilled applicants through point-based systems and shortage lists, thus enabling government actors to select migrants with desirable characteristics (Czaika, 2018). But national policies and regulations can also pose considerable obstacles to the workplace integration of highly skilled migrants, particularly for non-EU/EEA citizens. 
To be eligible for a residence permit in Norway, non-EU/EEA applicants must have received an offer of full-time employment for a position that offers remuneration commensurate with the median salary of native-born workers with equivalent qualifications. If granted, first-time residence permits are typically issued for 1-3 years and can be renewed (Norwegian Directorate of Immigration, 2016). EU/EEA citizens enjoy free movement within the EEA and just need to register with the local police within 3 months after arrival to obtain a registration certificate.

Non-EU/EEA citizens can experience long wait times to obtain a residence permit. Once they start working, they may have to wait for their personal identity number, which is required to earn a salary, open a bank account, and sign a phone contract (van Riemsdijk et al., 2015). These practical hurdles divert migrants' attention from their workplace integration. An engineer from Portugal compares his privileged position as an EU/EEA citizen to the experiences of his non-EU/EEA colleagues:

... for me, I'm-Portugal is part of the European community. And they have this - the Schengen Agreement. ... So it's - we don't need any specific, uh, like, permit to work here. So it's - it's very easy. You just go to the police, you show the contract from [the company], they give you a paper, you go to the tax office, you show the paper of the police. Uh, and then two weeks later, you get this...uh, national number. And with that number you go to the bank and you open an account. . . . People coming from-from countries outside the European community, they - it's more difficult for them. Like, if you are Brazilian, or from Pakistan. . ... (informant 36)

National policies govern the admission and entry of highly skilled voluntary migrants but do not cover their long-term integration. Government-sponsored introduction programs that inform about the labor market and workplace culture are developed for refugees (Buch et al., 2018). Highly skilled voluntary migrants receive practical assistance from government agencies at the local level, but do not qualify for government assistance with workplace integration. Private and voluntary actors fill this policy void, as discussed in more detail below.

\section{Local-Level Integration Initiatives}

\section{Service Center for Foreign Workers (SUA)}

Several cities have established welcome centers to assist newly arrived immigrants. These centers may offer practical assistance with the application for work permits and registration with the tax authorities, while others merely provide information and direct migrants to the responsible government agencies (e.g., in Portugal and Ireland, see Oliveira et al., 2009). The case workers in these centers act as brokers between national agencies, local authorities, and immigrants, bridging the missing link between government regulations at the national level and the delivery of services at the local level (Xiang, 2013).

The Norwegian government has established Service Centers for Foreign Workers (SUAs) in Oslo, Bergen, Stavanger, Trondheim, and Kirkenes, cities where a large 
number of foreign-born workers are employed. SUAs are designed as "one-stop-shops" where newly arrived immigrants can apply for a registration certificate (for EEA citizens), a residence permit (for non-EEA citizens), an identity number, and a tax deduction card. These government agencies are located in the same building, in theory enabling immigrants to register with all authorities in one day.

A labor migrant's visit to SUA is one of his or her first encounters with Norwegian bureaucracy. The case workers in the Tax Administration and the Norwegian Directorate of Immigration (UDI) communicate the government's expectations for a "good citizen" (Olwig, 2011), informing immigrants of their rights and responsibilities as workers and tax payers. In these activities, SUA centers play a key role as intermediaries in highly skilled migrants' integration (Harvey et al., 2017).

\section{Relocation Agencies}

Companies may hire relocation agencies to ease the integration of highly skilled migrants. These agencies provide practical support, including the application for residence permits, a national identity number, and tax card, searching for accommodation, and they may provide translation services. They may also offer an introduction to living and working in the receiving society, discussing working culture and professional habitus. Relocation agencies have local knowledge (about the housing market, schools, the transportation system), are aware of national policies and regulations, and know how to navigate the local administration (Tissot, 2018). Thus, the relocation agents link the migration regulations at the national level with the local administration and the needs of employers and foreign-born workers.

Several HR managers in our study have used the services of relocation agencies to ease the integration of high-level foreign-born workers. Relocation agencies have understood the importance of addressing the needs of all family members in order to retain highly skilled migrants long term (informant 2). They assist with the search for housing, child care, and schools if desired. Some agencies also offer language training for "trailing spouses." These services, however, are only available for "elite" skilled migrants whose employers are willing to pay. While none of the migrants included in this study were offered relocation services, we have elsewhere established the importance of these agencies in the integration of highly skilled migrants (van Riemsdijk, 2015).

\section{Companies}

In the absence of national integration initiatives, companies play a key role in the workplace integration of highly skilled migrants. Scholars have examined integration initiatives at the company level, as we discussed in the literature review (e.g., Friesen \& Ingram, 2013; Lai et al., 2017; Mahmud et al., 2014). In this section, we analyze company initiatives for the workplace integration of foreign-born workers and the consequences of a lack of assistance.

Once the new hires arrive, larger companies offer onboarding programs that familiarize employees with the company brand, rules and regulations, and workplace expectations. Some companies have also developed initiatives that bring together domestic and foreign workers, such as Young in Statoil. These organizations provide 
information about the company, offer social events for employees, and foster integration. One of our informants explains how this works:

you find new people who can work [to] network. . . . . in a very good mix of folks - Norwegian and non-Norwegian. . . . and Norwegians are very proud of their culture and of their customs, so they will try to transmit them to you. (informant 30)

These initiatives are particularly popular among immigrant employees, who are "the drivers of the social program" (informant 13).

Given the lack of regulatory standards, however, it is inevitable that employerdriven integration will be uneven. Some informants noted that their employers failed to provide practical assistance with housing, bureaucratic hurdles, and personal issues, causing significant - and avoidable-emotional distress (informant 63). A lack of assistance can result in the early departure of international hires, illustrated by two Portuguese engineers. They returned home within 2 weeks after arriving in Norway, as their coworker explains:

So they just, like dropped by parachute [into the job] . . . There's not much support from the company to...so like you have to take care of getting an apartment and - and finding a place to stay and normally you end up, like, in a - in a basement in the far, far end of the city. . . . and don't have a car or anything, it takes like one hour to walk to the city center, and after one hour you get to the city center and there's nobody there. . . . Some of the people, they get this shock. Because then they - they got here, and they see, well, it's, "I'm alone." (informant 36)

Another factor that contributes to early departures is related to family obligations. A study participant from South Asia may return to his country of origin when his aging father requires care (informant 58), confirming the relationship between migration, aging, and caring (Bailey et al., 2004; Baldassar, 2007). In addition, some immigrants cannot handle the rain and darkness in Norway. A recruitment agent explains: ". . . . if you hate nature and you hate bad weather like today [you will not succeed in Norway]" (informant 22). These factors cannot be controlled by companies, but the latter can ease the adjustment to life in Norway by providing practical assistance.

Integration assistance varies considerably between companies. A foreign-born engineer compared the company that he currently works for to his first employer. In his current employment in a large Norwegian company, he noted that

we need to ask our boss. When we need it [information about a particular issue], then they provide. . . We need to find for ourselves, we can't stay silent. (informant 54)

Thus, he needs to be proactive to receive the help that he needs. This was not the case in his previous employment in an American-owned company. He participated in an extensive onboarding program and he received a booklet, described by our informant as "twenty things you need to know:" 
The booklet says how to order things for workshops, equipment. How to fill in working hours, when you get sick, sick leave for children. If you have a community event, a bowling competition, and you need money, they give us money. How to contact people [if you need help] . . . a pool for renting car for free. A [company-owned] cabin, how to order it. (informant 54)

The information booklet helped him understand the rules and regulations for Norwegian welfare benefits, such as sick leave and care for his children, as well as companyspecific information about practical issues. In his new job, he is more dependent on his colleagues: "At lunchtime, they explain 'you get it [the information you need] from this one [person]' (ibid.)." Thus, informal networks are crucial when employers fail to assist newcomers.

The examples provided above raise the question: Who is responsible for the workplace integration of highly skilled migrants? Ideally, all actors involved take an active role, including managers and native-born and foreign-born employees (Lai et al., 2017). In practice, however, some companies fail to provide the necessary assistance. Voluntary organizations may fill that void in larger cities, as discussed in the next section.

\section{Voluntary Organizations}

In the absence of company-led assistance, some highly skilled migrants have founded their own associations to assist newcomers. These associations organize social gatherings and events for expatriates and native-born workers who have returned from assignments abroad (Beaverstock, 2011). Some organizations also provide practical assistance, informing newcomers about living and working in the host society (van Riemsdijk, 2015). These voluntary organizations fill a gap in the integration initiatives available to highly skilled migrants, bridging the disconnect between companies and migrants.

One informant in our study attended meetings organized by MeetUp (a website for building and finding local communities) and New to Oslo to make friends and learn about Norwegian working life. While these organizations primarily have a social mission, they also provide opportunities to discuss work-related issues (informant 36). The organization Norway International Network offers professional development workshops to foreign-born migrants, offering lectures on intercultural communication and how to ask for a raise. These initiatives provide information about working life to foreign-born workers, thus acculturating them to country-specific workplace norms.

\section{Personal-Level Integration Initiatives}

\section{Managers and Coworkers}

Human resource managers, line managers, and coworkers are key agents of integration in the workplace (van Riemsdijk et al., 2015). This process begins as early as the hiring interview, where managers inform prospective immigrant employees about living and working in the country of destination and gauge their suitability for the workplace 
(informant 43). Furthermore, some managers make it a point to hire candidates - both domestic and foreign - who express a genuine openness to working in an international environment (informant 13). As a line managers states:

some people are. . . . quite aware so when you put them in a team they're interested in understanding what the existing culture is, and. . . adapting to that and then having an influence over time. (informant 63)

For the company, the diversity of experience can increase productivity and innovation (Fatahi \& Riddle, 2010); for its employees, it imparts new skills that enhance professional development. Openness to diversity is integral to successful cross-cultural collaboration in the workplace, which in turn requires employer commitment to diversity management (Homan et al., 2008).

Despite the possible gains from a diverse workforce, cultural differences between foreign-born employees can pose significant integration challenges. An HR manager discussed the needs of employees from the USA and Africa, the latter "needing information about warm clothes, studded tires, overall, what is winter, compared to someone who actually has lived in a country with four seasons" (informant 9). He analyzes the integration challenges as follows:

[When you work in Norway] if you go to the coffee machine, you come from a man-dominated culture in the Middle East, there is no secretary, no lady who is going to [brew the coffee], it is something that we all do, it is a part of how it works here. If it is running low you make new coffee. It is the small unmentioned cultural things that happen. The other part, in Norway we are very used to having few procedures and guidelines. If you have to do a job, you have been given an assignment, you solve it with your intelligence and you have a high degree of freedom to complete it. In the US, for example, nothing happens if you don't have a procedure and someone has said that you have to do it this way. You can lose your job if you do something wrong or if you do something that is not described, that is a fundamental difference. . . Those are small things that together become very big. (informant 9)

These "small unmentioned cultural things" together add up to "big" integration challenges. HR managers and line managers play important roles in identifying, understanding, and valuing these differences, while managing diversity in the workplace (Friesen \& Ingram, 2013). These issues constitute a deeper level of workplace integration, going beyond the creation of social programs and the provision of practical information.

Coworkers also play an important role in the workplace integration of highly skilled migrants. Some companies offer buddy programs, linking a newcomer with a colleague who is familiar with company routines. These coworkers can provide practical information and insights into workplace norms and company culture. These social networks help foreign-born workers acquire valuable "soft" skills (Friesen, 2011).

Foreign-born line managers occupy positions that uniquely situate them to improve the situation for highly skilled migrants. They experienced the newcomer situation themselves and possess the knowledge and power to instigate change. One Western 
European line manager consciously diversified the composition of his team through targeted hires of foreign-born and female engineers to strengthen the multicultural skills and experiences of his team (informant 13). Another Western European line manager created a welcoming program after the company failed to accommodate his needs when he arrived in Norway (informant 63). These initiatives addressed the lack of diversity management in their companies, transitioning from ad hoc measures to a more structured approach to managing a diverse workforce (Friesen \& Ingram, 2013). These managers identified cracks in the workplace integration system and took it upon themselves to "scale up" their ideas to the company management level.

\section{Migrants}

In the sections above, we have identified a variety of actors involved in migrant integration in the workplace. As we have argued elsewhere, the personal characteristics of highly skilled migrants also shape integration processes in significant ways (van Riemsdijk et al., 2015). Personality traits such as sociability and openness to diversity and demographic variables like age, sex, family status, race/ethnicity, and country of origin intersect to produce differential outcomes for highly skilled migrants. These variables co-determine the integration trajectories of highly skilled migrants both inside and beyond the workplace. In this section, we discuss three of these variables, namely language proficiency, age, and family status.

A key factor in workplace integration is language proficiency. Although the petroleum industry is an international sector where English is widely spoken, some Norwegian companies and many domestic employees prefer to conduct business in Norwegian. Several informants were offered basic Norwegian language classes free of charge, even on company time. Nevertheless, language learning is a time-consuming process that is not feasible for some busy engineers, and it typically requires considerable effort beyond the courses provided by employers.

Migrants who learned to speak Norwegian were often motivated by a desire to improve the quality of their social lives, as this informant explains:

the thing is, [learning Norwegian is] not really required for me inside the office. All the documentation...it's okay in English, but then you're outside that door [that] world is living in Norwegian, so... at some point if you want to establish a network or friends...it's important [to speak Norwegian]. (informant 30)

These social connections are essential for more than just workplace conviviality, as the networking opportunities facilitated by language proficiency can be essential for career development. Language learning enhances employability, workplace efficiency, and social cohesion, but migrants typically have to make a significant effort to become proficient. These challenges suggest that employers and the state alike should prioritize language acquisition for skilled migrant workers (Derwing \& Waugh, 2012; Enchautegui, 2015).

To retain young, single employees, it is important that they thrive in the places where they live. These migrants may become bored when they are employed in small towns, as mentioned by informant 36 regarding the Portuguese engineers who left. In order to address this issue, one of the companies built a large onsite gym and tennis 
court and sponsors team sports. These initiatives offer meeting spaces for immigrants and native-born workers, where they can establish informal networks that can contribute to workplace integration (Smith et al., 2019; van Riemsdijk, 2014).

Foreign-born engineers with children praised Norway's generous family leave policies and the good work-life balance. An informant from South Asia compares working life in Norway with the Middle East, where she and her husband worked before coming to Norway:

If you see-if you compare to the Middle East, I know it's, like, life is very fast, and you do not get time to do everything. But here [in Norway], it's opposite. We have time to spend with the family. We have time for everything. (informant 35)

Similarly, an engineer from Southern Europe praises the work-life balance in the company that he works for:

They say that we want our employees to have their own private lives, to have their own, uh, balanced living, which is something that I'm definitely not used to in Portugal. . . Sometimes, you might think, "Well, that is what they say." But it is actually true. My colleagues that have families, they - they can very easily take some time to be with their family. And no one will ever say that that is not the way to go. It is, uh, pretty clear that, in here, you, eh, if you prioritize family, your career will not suffer. (informant 30)

In order to retain highly skilled migrants long term, it is important that their spouse and children accompany them to Norway. One company requires family members to move within 1 year of the contract starting date, to lower the risk that the foreign-born employee leaves (informant 9). To incentivize spouses, some companies offer dual hires or job search assistance (informants 9 and 11). These initiatives help retain immigrants with dual careers (Hardill, 2004; Shinozaki, 2014).

In this section, we have discussed some of the personal factors that shape the workplace integration of highly skilled migrants. Taken together, these factors shape diverging integration needs. Companies and managers need to be aware of these different experiences to be able to provide the integration services that migrants need. Training in diversity management is one way to anticipate and address the diverging experiences and needs of highly skilled migrants (Friesen \& Ingram, 2013; Homan et al., 2008).

\section{Discussion and Concluding Remarks}

In this article, we have identified key actors that are involved in the integration of highly skilled migrants, their integration strategies, and the inter-linkages and missing links between these actors across levels of authority. The multi-level framework provides three key insights into immigrant integration in general and the integration of highly skilled migrants in the workplace in particular. 
First, the framework complicates the understanding of integration as a two-way interaction between immigrants and institutions of the host society, a commonly held assumption by migration scholars. Our framework shows the multitude of actors that are involved in immigrant integration efforts at different levels. The interactions between migrants and various integration actors take place concurrently, thus constituting a multi-actor, multi-directional integration system. The primacy of actors, however, will vary for different categories of migrants.

The multi-level framework can be adapted to other professions, identifying additional actors, relations between levels and (dis)connects. In nursing, for example, professional authorization and certification requirements can pose considerable obstacles for foreign-born nurses (van Riemsdijk, 2013). Thus, recognition bodies and professional organizations are powerful gatekeepers to the profession. Trade unions can empower foreign-born nurses by teaching them about national employment regulations and employee rights, and they can provide legal assistance when necessary (van Riemsdijk, 2010). In addition, recruitment agencies can assist foreign-born nurses with practical issues, including language courses, the application for authorization, travel, accommodation, and information about workplace norms and values. As foreign-born nurses are indebted to these agencies, however, the agencies can take advantage of them (Knutsen et al., 2019). This example shows that professions have a particular set of key actors that shape the workplace integration of highly skilled migrants, with profession-specific inter-linkages and disconnects.

Second, we have identified several instances of fragmentation in the integration of highly skilled migrants in the workplace. In the governance void resulting from a lack of state oversight and guidelines for the integration of highly skilled migrants, public and private stakeholders link integration actors across international, national, and/or local levels of governance. EURES links employers and job seekers across national borders and provides information about Norwegian working culture and society. Service Centers for Foreign Workers (SUA) and relocation agencies create links between national regulations and local service delivery. Companies, human resource managers, line managers, and coworkers may provide local assistance as well. Some companies offer on-boarding programs and language courses, while others place the burden on migrants to integrate. The latter case requires a high level of agency of migrants to succeed in the receiving country.

The responsibility for integration by local private and voluntary actors can be explained by a larger trend in the devolution of the provision of social services to local institutions (van Riemsdijk, 2010). This involvement of local actors can be beneficial to the integration of immigrants, as they have a better understanding of the needs of immigrants and can better tailor their services than national-level public agencies (Boushey \& Luedtke, 2006). The devolution of public services is also evident in integration services for refugees, as identified in a "local turn" in immigrant policies (Zapata-Barrero et al., 2017). The extent to which local authorities have decisionmaking power in these issues depends, however, on the governance structure of the receiving country (Boushey \& Luedtke, 2006).

Third, we have shown that highly skilled migrants can be significant agents of integration, as they have some agency to "scale up" initiatives to higher levels of authority. They identify cracks in integration initiatives between levels and use these to instigate change (Xiang, 2013: 285). Highly skilled migrants likely exert greater control 
over this process than low-skilled migrants, given their position of relative privilege and power. Their agency, however, is modified by various actors in the host country, as illustrated by the downward arrows in our multi-level framework.

This case study has provided insights into the workplace integration process for highly skilled migrants in one profession (engineers in the oil and gas industry) in one country (Norway). The integration actors and processes that we have identified are to a certain extent profession and context specific. We hope that our conceptual framework will inform studies of highly skilled migrant integration in other professions and other countries. A broader scope of integration sites, actors, inter-linkages, and missing links will provide deeper insights into the integration process for highly skilled migrants.

Acknowledgements The research for this article was supported by the US National Science Foundation (grant 1155339) and the Center for International and Regional Studies at Georgetown University, Qatar. We appreciate the research assistance provided by Alana Burnham, Matt Cook, Jaylyn Johnson, and Ben Todd and thank Zahra Babar, Michael Ewers, Nabil Khattab, and Mehran Kamrava for helpful comments on an earlier version of this article.

Funding Open access funding provided by Uppsala University.

Open Access This article is licensed under a Creative Commons Attribution 4.0 International License, which permits use, sharing, adaptation, distribution and reproduction in any medium or format, as long as you give appropriate credit to the original author(s) and the source, provide a link to the Creative Commons licence, and indicate if changes were made. The images or other third party material in this article are included in the article's Creative Commons licence, unless indicated otherwise in a credit line to the material. If material is not included in the article's Creative Commons licence and your intended use is not permitted by statutory regulation or exceeds the permitted use, you will need to obtain permission directly from the copyright holder. To view a copy of this licence, visit http://creativecommons.org/licenses/by/4.0/.

\section{References}

Bailey, A. J., Blake, M. K., \& Cooke, T. J. (2004). Migration, care, and the linked lives of dual-earner households. Environment and Planning A, 36(9), 1617-1632.

Baldassar, L. (2007). Transnational families and aged care: The mobility of care and the migrancy of ageing. Journal of Ethnic and Migration Studies, 33(2), 275-297.

Baskerville, R. F. (2003). Hofstede never studied culture. Accounting, Organizations and Society, 28(1), 1-14.

Baxter, J., \& Eyles, J. (1996). Evaluating qualitative research in social geography: Establishing 'rigour' in interview analysis. Transactions of the Institute of British Geographers, 22, 505-525.

Beaverstock, J. V. (2011). Servicing British expatriate 'talent' in Singapore: Exploring ordinary transnationalism and the role of the 'expatriate' club. Journal of Ethnic and Migration Studies, 37(5), 709-728.

Boushey, G., \& Luedtke, A. (2006). Fiscal federalism and the politics of immigration: Centralized and decentralized immigration policies in Canada and the United States. Journal of Comparative Policy Analysis, 8(3), 207-224.

Brochmann, G., \& Djuve, A. B. (2013). Multiculturalism or assimilation? The Norwegian welfare state approach. In P. Kivisto \& Ö. Wahlbeck (Eds.), Debating multiculturalism in the Nordic welfare states (pp. 219-245). Springer.

Buch, A., Berthou, S. K. G., \& Bredgaard, T. (2018). Refugees and immigrants in the Nordic. Nordic Journal of Working Life Studies, 8(S4), 1-5.

Czaika, M. (2018). High-skilled migration: Drivers and policies. Oxford University Press.

de Haas, H., Castles, S., \& Miller, M. J. (2020). The Age of Migration: International Population Movements in the Modern World (6th ed.). Palgrave Macmillan. 
Derwing, T. M., \& Waugh, E. (2012). Language skills and the social integration of Canada's adult immigrants. IRPP Study, 31, 1.

Ekeland, A. (2017). Sysselsatte i petroleumsnaeringene og relaterte nceringer 2016 (0806-2056). Statistics Norway.

Ellis, M., \& Almgren, G. (2009). Local contexts of immigrant and second-generation integration in the United States. Journal of Ethnic and Migration Studies, 35(7), 1059-1076.

Enchautegui, M. E. (2015). Engaging employers in immigrant integration. Urban Institute.

Esping-Andersen, G. (1996). Welfare states in transition: National adaptations in global economies. Sage.

European Commission. (2020). EURES: The European job mobility portal. Retrieved from https://ec.europa. eu/eures/public/homepage. Accessed 15 Oct 2020.

Fatahi, B., \& Riddle, S. O. (2010). Competency ingredients for the successful petroleum professional in the new millennium. In D. H. Johnston \& M. R. Cooper (Eds.), Methods and applications in reservoir geophysics (pp. 37-48). Society of Exploration geophysicists.

Feltenius, D. (2016). Subnational government in a multi-level perspective. In J. Pierre (Ed.), The Oxford handbook of Swedish politics (pp. 383-398). Oxford University Press Oxford.

Friesen, M. (2011). Immigrants' integration and career development in the professional engineering workplace in the context of social and cultural capital. Engineering Studies, 3(2), 79-100.

Friesen, M., \& Ingram, S. (2013). Advancing intercultural competency: Canadian engineering employers' experiences with immigrant engineers. European Journal of Engineering Education, 38(2), 219-227. https://doi.org/10.1080/03043797.2013.766677.

Gerhart, B., \& Fang, M. (2005). National culture and human resource management: Assumptions and evidence. International Journal of Human Resource Management, 16(6), 971-986.

Girard, E. R., \& Bauder, H. (2007). Assimilation and exclusion of foreign trained engineers in Canada: Inside a professional regulatory organization. Antipode, 39(1), 35-53.

Groutsis, D., van den Broek, D., \& Harvey, W. S. (2015). Transformations in network governance: The case of migration intermediaries. Journal of Ethnic and Migration Studies, 41(10), 1558-1576.

Guttormsen, D. (2016). Looking forward by looking back': A transdisciplinary self/other perspective on intercultural expatriate research. In N. Holden, S. Michailova, \& S. Tietze (Eds.), The Routledge Companion to Cross-Cultural Management. Routledge.

Hardill, I. (2004). Transnational living and moving experiences: Intensified mobility and dual-career households. Population, Space and Place, 10(5), 375-389.

Harvey, W. S., Groutsis, D., \& van den Broek, D. (2017). Intermediaries and destination reputations: Explaining flows of skilled migration. Journal of Ethnic and Migration Studies, 1-19.

Harzing, A. (2001). An analysis of the functions of international transfer of managers in MNCs. Employee Relations, 23(6), 581-598.

Hernes, V., Arendt, J. N., Joona, P. A., \& Tronstad, K. R. (2019). Nordic integration and settlement policies for refugees: A comparative analysis of labour market integration outcomes. Nordic Council of Ministers.

Hofstede, G. H., Hofstede, G. J., \& Minkov, M. (2005). Cultures and organizations: Software of the mind (2nd ed.). Mcgraw-Hill New York.

Homan, A. C., Hollenbeck, J. R., Humphrey, S. E., Van Knippenberg, D., Ilgen, D. R., \& Van Kleef, G. A. (2008). Facing differences with an open mind: Openness to experience, salience of intragroup differences, and performance of diverse work groups. Academy of Management Journal, 51(6), 1204-1222.

International Organization for Migration. (2019). World Migration Report 2020. International Organization for Migration.

International Organization of Migration. (2019). World migration report 2020. International Organization of Migration.

Knutsen, H. M., Fangen, K., \& Žabko, O. (2019). Integration and exclusion at work: Latvian and Swedish agency nurses in Norway. Journal of International Migration and Integration, 1-17.

Koopmans, R. (2010). Trade-offs between equality and difference: Immigrant integration, multiculturalism and the welfare state in cross-national perspective. Journal of Ethnic and Migration Studies, 36(1), 1-26.

Kymlicka, W. (2012). Multiculturalism: Success, failure, and the future.

Lai, D. W., Shankar, J., \& Khalema, E. (2017). Unspoken skills and tactics: Essentials for immigrant professionals in integration to workplace culture. Journal of International Migration and Integration, 18(3), 937-959.

Lindquist, J., Xiang, B., \& Yeoh, B. S. (2012). Opening the black box of migration: Brokers, the organization of transnational mobility and the changing political economy in Asia. Pacific Affairs, 85(1), 7-19.

Mahmud, S., Alam, Q., \& Härtel, C. (2014). Mismatches in skills and attributes of immigrants and problems with workplace integration: A study of IT and engineering professionals in Australia. Human Resource Management Journal, 24(3), 339-354. https://doi.org/10.1111/1748-8583.12026.

McSweeney, B. (2002). Hofstede's model of national cultural differences and their consequences: A triumph of faith-a failure of analysis. Human Relations, 55(1), 89-118. 
Norwegian Directorate of Immigration. (2016). Residence permit for skilled workers. Retrieved from https:// www.udiregelverk.no/en/documents/udi-circulars/rs-2014-018/. Accessed 3 Jun 2017.

Oliveira, C. R., Abranches, M., \& Healy, C. (2009). Handbook on how to implement a one-stop-shop for immigrant integration: Observatório da Imigração. ACIDI.

Olwig, K. F. (2011). 'Integration': Migrants and refugees between Scandinavian welfare societies and family relations. Journal of Ethnic and Migration Studies, 37(2), 179-196.

Plöger, J., \& Becker, A. (2015). Social networks and local incorporation-Grounding high-skilled migrants in two German cities. Journal of Ethnic and Migration Studies, 41(10), 1517-1535.

Salt. (1997). International movements of the highly skilled. Organization for Economic Cooperation and Development.

Sandnes, T. (2017). Innvandrere i Norge [Immigrants in Norway]. Statistics Norway.

Shenkar, O. (2001). Cultural distance revisited: Towards a more rigorous conceptualization and measurement of cultural differences. Journal of International Business Studies, 32(3), 519-535.

Shinozaki, K. (2014). Career strategies and spatial mobility among skilled migrants in Germany: The role of gender in the work-family interaction. Tijdschrift voor Economische en Sociale Geografie, 105(5), 526-541.

Smith, R., Spaaij, R., \& McDonald, B. (2019). Migrant integration and cultural capital in the context of sport and physical activity: A systematic review. Journal of International Migration and Integration, 20(3), 851-868.

Spencer, S. (2017). Multi-level governance of an intractable policy problem: Migrants with irregular status in Europe. Journal of Ethnic and Migration Studies, 44, 1-19. https://doi.org/10.1080/1369183X.2017. 1341708.

Statistics Norway. (2019). Arbeidsinnvandringen øker igjen [Labor migration increases again]. Retrieved from https:/www.ssb.no/befolkning/artikler-ogpublikasjoner/flest-innvandrer-pa-grunn-av-arbeid. Accessed 27 May 2019.

Statistics Norway (2021). Innvandrere og norskfødte med innvandrerforeldre [immigrants and Norwegianborn with immigrant parents]. Retrieved from https:/www.ssb.no/innvbef. Accessed 15 Mar 2021.

Tissot, F. (2018). A migration industry for skilled migrants: The case of relocation services. Migration Letters, 15(4), 545-559.

Tønnessen, M., Cappelen, Å., \& Skjerpen, T. (2017). Innvandringen synker raskere enn antatt [Immigration declines faster than anticipated]. Retrieved from https:/www.aftenposten.no/meninger/debatt/i/8499w/ Innvandringen-synker-raskere-enn-antatt\%2D\%2DTre-forskere-i-Statistisk-sentralbyra. Accessed 28 May 2019.

van Riemsdijk, M. (2010). Neoliberal reforms in elder care in Norway: Roles of the state, Norwegian employers, and Polish nurses. Geoforum, 41(6), 930-939.

van Riemsdijk, M. (2013). Obstacles to the free movement of professionals: Mutual recognition of professional qualifications in the European Union. European Journal of Migration and Law, 15(1), 47-68.

van Riemsdijk, M. (2014). International migration and local emplacement: Everyday place-making practices of skilled migrants in Oslo, Norway. Environment and Planning A, 46, 963-979.

van Riemsdijk, M. (2015). Agents of local incorporation: Skilled migrant organizations in Oslo, Norway. In L. Meier (Ed.), Migrant Professionals in the City: Local Encounters, Identities, and Inequalities (pp. 77-97). Routledge.

van Riemsdijk, M., Basford, S., \& Burnham, A. (2015). Socio-cultural incorporation of skilled migrants at work: Employer and migrant perspectives. International Migration, 54(3), 20-34. https://doi.org/10.1002/psp.2005.

van Riemsdijk, M., \& Wang, Q. (Eds.). (2017). Rethinking international skilled migration. Routledge.

Verwiebe, R., Mau, S., Seidel, N., \& Kathmann, T. (2010). Skilled German migrants and their motives for migration within Europe. Journal of International Migration and Integration, 11(3), 273-293.

Wimmer, A., \& Glick Schiller, N. (2003). Methodological nationalism, the social sciences, and the study of migration: An essay in historical epistemology. International Migration Review, 37(3), 576-610.

Xiang, B. (2012). Predatory princes and princely peddlers: The state and international labour migration intermediaries in China. Pacific Affairs, 85(1), 47-68.

Xiang, B. (2013). Multi-scalar ethnography: An approach for critical engagement with migration and social change. Ethnography, 14(3), 282-299.

Zapata-Barrero, R., Caponio, T., \& Scholten, P. (2017). Theorizing the 'local turn' in a multi-level governance framework of analysis: A case study in immigrant policies. International Review of Administrative Sciences, 83(2), 241-246.

Publisher's Note Springer Nature remains neutral with regard to jurisdictional claims in published maps and institutional affiliations. 